\title{
UCIECZKA Z UTOPII W HISTORIĘ. MIŃSK ARTURA KLINAUA
}

\author{
LAJOS PÁlFALVI ${ }^{1}$ \\ (Pázmány Péter Katolikus Egyetem, Budapest)
}

Słowa kluczowe: Artur Klinau, Mińsk, utopia, rosyjski kolonializm, tożsamość białoruska

Key words: Artur Klinau, Minsk, utopia, Russian colonialism, Belarusian identity

\begin{abstract}
Abstrakt: Lajos Pálfalvi, UCIECZKA Z UTOPII W HISTORIĘ. MIŃSK ARTURA KLINAUA. „PORÓWNANIA” 14, 2014, T. XIV, s. 207-220. ISSN 1733-165X. Artur Klinau przedstawia rodzime miasto w ujęciu klasycznej utopii campanellowskiej. W dwóch wiekach historii kolonialnej Mińsk był tylko jedną z licznych planet, krążących wokół Moskwy, gdzie komunistyczne dzieci śpiewały hymn o słońcu: Пусть всегда будет солнще. Twórcy utopii pozbawili Mińsk historii, w ten sposób nie pozostało nic w przestrzeni miejskiej, co mogłoby przeszkodzić w realizacji projektu. Miasto Słońca było częścią ogromnej kompozycji eurazyjskiej, budowanej jako łuk triumfalny, wrota prowadzące do Moskwy. Solarna symbolika władzy przywodzi na myśl wschodnią autokrację. Miasto przypomina Persepolis, centrum sakralne, które władca odwiedza podczas równonocy wiosennej, przyjmując hołd poddanych. Ciąg pałaców Mińska wygląda jak dwa rzędy dekoracji. Jeśli chcielibyśmy opisać Prospekt za pomocą postmodernistycznej terminologii architektonicznej, dobrze posłuży nam w tym celu klasyczny przykład Las Vegas, podany przez Roberta Venturiego. Ciąg pałaców tak samo oddziela się od otoczenia, jak commercial strip od pustyni. Z tego świata iluzji bohater ucieka do historii prekolonialnej.
\end{abstract}

\begin{abstract}
Lajos Pálfalvi, THE ESCAPE FROM UTOPIA TO HISTORY. ARTUR KLINAU'S MINSK. „PORÓWNANIA” 14, 2014, Vol. XIV, p. 207-220. ISSN 1733-165X. Artur Klinau describes his home town like Capanella's classic utopia. During the two centuries of colonial history Minsk was only one of the several planets orbiting around Moscow, the city where communist children sang their Anthem to the Sun: Пусть всегда будет солнце. The creators of the utopia had deprived Minsk of its history, therefore the city no longer possessed anything that could have stopped the project. Sun City was part of an enormous Eurasian composition. It was built as a triumphal arch, as a gate to Moscow. The solar symbol of power reminds us of oriental despotism. It recalls Persepolis, the sacred centre visited by the emperor at the time of the vernal equinox to receive the dependents' homage. The two rows of palaces in Minsk look like decora-
\end{abstract}

\footnotetext{
${ }^{1}$ Correspondence Address: idegentoll@t-online.hu
} 
tion of a scenery. Using the terminology of postmodern architecture, the Prospect might be properly described with Robert Venturi' classical instance of Las Vegas. The two rows of palaces stand out of their environment just like the commercial strip stands in contrast to the desert. The protagonist runs away from this world of illusions to the precolonial history.

Artur Klinau urodził się w Mińsku w połowie lat sześćdziesiątych, na początku epoki Breżniewa. Odsunięty rok wcześniej od władzy Chruszczow przewidział na początku dekady, że komunizm urzeczywistni się najpierw w Białoruskiej Socjalistycznej Republice Radzieckiej, ponieważ tam najszybciej zapomną języka ojczystego. Myśl wydaje się logiczna, bowiem kto chce dołączyć do społeczeństwa przyszłości, musi zrezygnować ze wszystkiego, co łączy go z przeszłością, szczególnie zaś ze swojej tożsamości kulturowej, symbolizowanej przez język ojczysty. $\mathrm{Z}$ drugiej jednak strony, myśl ta jest absurdalna, bowiem komunistyczna utopia zasadniczo nie jest powiązana z żadną rytualną mową, każdy naród może chwalić swego władcę we własnym języku. Chociaż Chruszczow mówił o bliskim urzeczywistnieniu się utopii, tak naprawdę odkrył bardzo ziemską naturę Związku Radzieckiego, deklarując, że na peryferiach mocarstwa nie mogą się ostać tożsamości różne od centralnych.

W jego przepowiedni mowa jest też o tym, że $w$ tej republice opór jest najmniejszy: kultura białoruska nie różni się od moskiewskiej tak bardzo jak kaukaska czy środkowo-azjatycka (obie nie do zniszczenia pokojowymi środkami), nie ma tu tradycji niepodległej państwowości, jak w krajach bałtyckich, a proces tworzenia się narodu nie doszedł do etapu masowej agitacji, jak na zachodnich terenach Ukrainy. To tłumaczy także w dużej mierze fakt, dlaczego białoruski projekt etnonarodowy z lat dziewięćdziesiątych zakończył się porażką, kiedy komunistyczną utopię zastąpił peryferyjny kapitalizm.

Artur Klinau w książce pt. Mińsk. Przewodnik po Mieście Słońca przedstawia rodzinne miasto w ujęciu klasycznej utopii campanellowskiej. Rządzący do swojej śmierci w 1982 roku pierwszy sekretarz staje się głową państwa i kapłanem, zwanym Słońcem, choć mieszkańcy mówią na niego „Metafizyk”. Solarna symbolika władzy przywodzi na myśl nie tylko Campanellę, ale także wschodnią autokrację, niszczącą europejską tożsamość miasta. Mińsk, zwany Miastem Słońca, staje się sceną stworzoną według woli despoty, głoszącą chwałę samowładztwa, miejscem niemal nie z tej ziemi. Przypomina Persepolis, nie stolicę mocarstwa, lecz centrum sakralne, które władca odwiedza podczas równonocy wiosennej, przyjmując hołd poddanych. To jest miejsce, w którym ludzkość może wyruszyć w przyszłość, ale już samo otoczenie architektoniczne przywodzi na myśl świat, do którego dotrze. Miasto Słońca jest apoteozą imperium. W jednym z polskich studiów o Dostojew- 
skim można przeczytać, że „słońcem każdego prześladowczego imperium był imperator, basileus, car". Tam też mowa jest o wywodzącej się z kultury irańskohelleńskiej proskynezie. To swoista forma hołdu: „jeśli poddany został dopuszczony przed oblicze cesarza, (...) musiał upaść do nóg cesarza z rozpostartymi ramionami i ucałować jego stopy"2. Jedną z odmian proskynezy wprowadzono także na dworze carskim.

Twórcy opisujący utopie formułują konkretne wyobrażenia o idealnym systemie społecznym, a ponieważ charakteryzuje ich nowożytna potrzeba uniwersalizmu, umiejscowienie nie ma znaczenia, odległa wyspa jest tylko geograficzną konwencją, tworzącą przeciwwagę dla pustki abstrakcji. We współczesnej literaturze na podobnej zasadzie przedstawia się wielkie miasta jako widmowe aglomeracje. Wiedeń Roberta Musila czy Petersburg Fiodora Dostojewskiego, który wypierał się białoruskiego pochodzenia, to unreal cities, które są "pozbawione nazwy, realiów geograficznych, regionalnych czy narodowych", bowiem tylko tak mogą „pełnić funkcję uniwersalnych alegorii nowoczesności”3. W modernizmie główną rolę odgrywało miasto konceptualne, rozumiane jako ziszczenie się założeń urbanistycznych i racjonalistycznego funkcjonalizmu, w postmodernistycznym regionalizmie zastępuje je miasto znane $z$ doświadczenia, z codziennej praktyki, które nie jest teoretyczną konstrukcją podporządkowaną mapie, ale przestrzenią na wyciągnięcie ręki, widzianą od środka, z perspektywy niespiesznego przechodnia. Wskutek tej zmiany perspektywy skłonni jesteśmy podważać lub unieważniać poprzednią wersję ${ }^{4}$ U Klinaua ten wariant staje się antytezą wersji pojęciowej.

Przechodzień w Mieście Słońca poznaje powiązane z rozpoznawalnym geograficznie miejscem dekoracje, próbujące uwiarygodnić urzeczywistnienie utopii. Nie jest ciekawskim turystą, ale rdzennym mieszkańcem narzuconej krajowi utopii, która go uformowała - z książki dowiadujemy się też, jak się z niej wyzwolił. To także związana z konkretnym miejscem osobista historia, która właśnie dlatego odniosła sukces. Podaje się liczne uniwersalne recepty na wyrwanie się z utopii, które łączą argumenty demokratyczne i konsumenckie (masz swoje prawa, należy ci się więcej za twoje osiągnięcia), jednak nie ma w nich konkretów geograficznych, tak jak i brak ich w samej utopii, dlatego też często przynoszą jedynie pozorne efekty.

Ciąg myślowy Klinaua zbudowany jest na przeciwstawieniu sobie utopii i historii. Utopia dlatego zrodziła się u zarania nowożytności, kiedy przeczuwano przemiany społeczne, bowiem niektórzy myśliciele szukali ucieczki z konkretnych pułapek historii, które powstały z powodu hamujących rozwój społeczny form

2 R. Przybylski, M. Janion, Sprawa Stawrogina. Warszawa 1996, s. 9.

${ }^{3}$ E. Rybicka: Geopoetyka (o mieście, przestrzeni i miejscu we wspótczesnych teoriach i praktykach kulturowych. W: Kulturowa teoria literatury. Główne pojęcia i problemy. Red. M. P. Markowski, R. Nycz. Kraków 2006, s. 481.

${ }^{4}$ Por. ibidem, s. 474. 
sprawowania władzy. Utopia ofiarowała wolność, jednak potomność często odczytuje książki o niej tak, jakby znajdującemu się w sytuacji bez wyjścia autorowi udało się wyobrazić działającą na innych zasadach, być może straszliwszą, tyranię. Kiedy przy końcu nowożytności totalitaryzm był postrzegany jako urzeczywistniona utopia, zrodziła się utopia negatywna, która, wychodząc z realiów nazistowskich i sowieckich, pokazywała abstrakcyjniejszy świat, sugerując, że historia $\mathrm{w}$ nieunikniony sposób podąża $\mathrm{w}$ tym kierunku i że $\mathrm{z}$ tej sytuacji nie ma już wyjścia.

U Klinaua utopia pozbawia jednostkę historii, tutaj przeszkodą rozwoju spolecznego nie jest konkretna sytuacja historyczna, utopia po prostu przerywa ciągłość historyczną, likwidując tym samym białoruską tożsamość kulturową. To jest takie doświadczenie, którego wyzwalająca się spod władz sowieckich, reprezentująca społeczeństwa o słabej tożsamości inteligencja nie potrafiła wytłumaczyć Zachodowi (słaba tożsamość w przypadku Białorusinów i Ukraińców oznacza, że jako członkowie niegdysiejszej wschodniosłowiańskiej, ortodoksyjnej wspólnoty wyznaniowej i spadkobiercy wspólnej radzieckiej przeszłości, nie odróżniają siebie samych w jednoznaczny i zdecydowany sposób od Rosjan, choć, oczywiście, nie uważają się też za nich).

Jurij Andruchowycz opisuje, jak pewien szwedzki profesor pouczał go, że „historia nie jest potrzebna szczęśliwym społeczeństwom" i tylko nieszczęśliwe szukają $\mathrm{w}$ niej samousprawiedliwienia. „Przedstawiciele społeczeństw nieszczęśliwych" $^{\prime \prime}$ całych sił wypierają się takiego podejścia, mówiąc, że totalitaryzm pozbawił ich właśnie historii i teraz muszą ją odzyskać. Nie mają jej wiele, wręcz zbyt mało. Dla Zachodu historia jest "zamaskowaną mitologią", przyprawioną "domieszką ideologicznej nekrofilii", należy się od niej uwolnić, bowiem w przeciwnym wypadku nie można „liczyć na szybką integrację z Wewnętrzną Europą, wierną liberalno-kosmopolitycznym i konsumpcyjno-hedonistycznym wartościom" 5 .

To tak, jakby inteligencja doświadczonych oboma totalitaryzmami postkomunistycznych krajów słyszała od Zachodu: wpuszczę was, ale nie możecie wnieść swoich doświadczeń historycznych, mam przepełnioną pamięć, zresztą i tak nie zmienię moich aksjomatów polityki pamięci. Nie możecie przepracować tych traum, które spowodowała rosyjska i sowiecka kolonizacja. Polscy historycy literatury badający postkolonializm stwierdzili już, że Zachód w takim momencie występuje jako hegemon zastępczy. Stworzył na peryferiach wschodnioeuropejskich tę mroczną strefę, względem której jego własny rozwój wydaje się imponujący i przykładowy, jest nawet skłonny ukazywać Rosję jako siłę napędową rozwoju. Historię i kulturę narodów wciśniętych pomiędzy Niemców i Rosjan poddają orientalizacji nawet najbardziej poważani badacze, jak Tony Judt i Larry Wolf,

${ }^{5}$ J. Andruchowycz, A. Stasiuk, Moja Europa. Wołowiec 2001, s. 25-27. 
przyczyniając się tym samym do ich marginalizacji i pogłębiając kompleks niższości społeczeństw postkolonialnych ${ }^{6}$.

Klinau szuka w historii ucieczki przed utopią. Choć odróżnia „projekt budowy Szczęścia od jego praktycznej realizacji", zaznacza, że ogromne fiasko można w większości tłumaczyć „stopniem degeneracji kodów moralnych nacji, która się jej podejmuje". Projekt komunistyczny w Związku Radzieckim „był projektem w istocie rzeczy rosyjskim", przypuszczalnie nie mógł być niczym innym, jako że „narody myślące nieco bardziej racjonalnie nie zaangażowałyby się w eksperyment tak totalny i od początku skazany na niepowodzenie" 7 . Dlatego też Klinau musiał cofnąć się $\mathrm{w}$ ramach historii do momentu, kiedy kraj nie był jeszcze okupowany przez Rosjan.

Tereny białoruskie stały się zachodnią prowincją Imperium Rosyjskiego w XVIII wieku, po rozpadzie Polski, a dokładniej - wspólnego państwa polskolitewskiego. W Klinauowskim pojmowaniu historii był to początek kolonizacji moskiewskiej - tam można doszukiwać się korzeni procesu podążającego w stronę likwidacji tożsamości. Umiejscowione na linii podziału cywilizacji, niedysponujące współczesną świadomością narodową społeczeństwo przedostało się drogą podbojów z regionu środkowoeuropejskiego, wykształconego pomiędzy Niemcami a Rosjanami, do Eurazji, pod panowanie carów wkraczających w dziedzictwo władcy wielkich stepów Czyngis-chana. Tę zmianę kierunku, pociągającą za sobą nieznane konsekwencje, wyraża zawarta w książce solarna symbolika władzy.

Bez zaprzeczania wewnętrznemu rozwojowi kultury białoruskiej i przetrwaniu skazanych na podziemne życie tradycji zmuszeni jesteśmy przeciwstawić sobie osiemset lat historii prekolonialnej i ponad dwa stulecia, które po nich nastąpiły. To samo zresztą, lecz z przeciwnym znakiem uczynili apologeci kolonizacji moskiewskiej. Wedle tego podejścia każda Albaruthenia stanowi zachodnie peryferie Moskwy, która przejęła dziedzictwo Kijowa, a jej mieszkańcy to zachodni Rosjanie. To niegdyś samorządne księstwo po osłabiającym Państwo Kijowskie najeździe Tatarów dostało się jednak pod władzę litewską, a później polskolitewską, zdeformowało się pod obcymi rządami jako "porwany Wschód”, jego dzieje nie należą do ojczystej, lecz do zagranicznej historii, nie mają zatem żadnego sensu ani wagi. Przeszłość Mińska to przeszłość Rusi Kijowskiej i Moskiewskiej, a także Imperium Rosyjskiego, choć miasto to stało się częścią tego ostatniego dopiero po rozbiorze Polski w 1772 roku. Nie ma zatem nic wspólnego z tym, co działo się przed rozbiorem Polski na dzisiejszych ziemiach białoruskich (nie licząc okresu kijowskiego, trwającego od 1130 do 1307 roku).

${ }^{6}$ D. Skórczewski, Polska skolonizowana, Polska zorientalizowana. Teoria postkolonialna wobec „innej Europy”. „Porównania” 2009, nr 6, s. 95.

7 A. Klinau, Mińsk. Przewodnik po Mieście Słońca. Przeł. M. Buchalik. Wołowiec 2006, s. 12. 
Moskwa w drugiej połowie XIX wieku wystąpiła z potrzebą określenia tożsamości Białorusinów, kiedy to ideologia imperialna nabrała charakteru rosyjskiego dążenia etnonacjonalistycznego. Jeden z interesujących się kwestią narodowości ideologów słowianofilskich, Jurij Samarin, postrzegał polską kulturę jako dualistycznego mutanta, rozdartego między łacińskością i słowiańskością. Iwan Aksakow uważał z kolei, że Polska ma tylko jednego, łacińskiego ducha i na zawsze jest stracona dla słowiańskości. Dla Polaków nie ma już ratunku, dlatego też Białorusinów i Ukraińców (Małorosjan) należy odseparować od Warszawy i powiązać z Moskwą. Według Aksakowa, Białorusini byli „zachodnią odmianą Rosjan, różniącą się od Wielkorusów głównie tym, że poddawano ją przez wieki naporowi katolicyzmu i demoralizującemu wpływowi spolonizowanych warstw wyższych" ${ }^{8}$. Rozwiązaniem jest konsekwentna rusyfikacja administracyjna „zachodniej części kraju" (obrusenie). W ten sposób, zjednoczeni losem z Rosjanami Białorusini dotarli do tryumfu komunizmu, razem zapoczątkowali urzeczywistnienie tej idei (choć odwieczny wróg na dwie dekady zrabował zachodnie tereny).

Jeśli książkę Klinaua czytamy jako autobiografię duchową, widzimy, że bohater rodzi się w Utopii zwanej Krainą Szczęścia, gdzie Mińsk to tylko jedna z licznych planet, krążących wokół Moskwy. Jego znaczenie nie może być porównywane z Leningradem, uświęconym jako kolebka rewolucji. Z grubsza rzecz biorąc, jego status jest taki, jak oddalonego o dwa tysiące kilometrów Wołgogradu, niegdysiejszego Stalingradu. Główny bohater poznaje miasto $\mathrm{w}$ wieku trzynastu lat, podczas wycieczki klasowej, i wtedy też odkrywa charakterystyczny styl Miasta Słońca, choć „nie prezentował się aż tak wspaniale”: „identyczne szerokie ulice w centrum, domy przypominające pałace, sztukaterie, wazy, kolumny i rzeźby" (s. 64).

Później Klinau widzi te dekoracje w najróżniejszych częściach kraju. Łatwo jest odgadnąć, co łączy Mińsk i inne miasta, rozsiane po Imperium wielkości kontynentu. Niemal niemożliwe jest natomiast rozszyfrować, co Mińsk od nich odróżnia. Szkoły w Mieście Słońca dostarczyły odpowiedzi tylko na pierwsze pytanie, do drugiego wniosku można było dojść jedynie dzięki indywidualnej ewolucji duchowej. Trudno wybrać tę drogę, bowiem w tym celu trzeba przezwyciężyć stan egzystencji obywatela budującego Krainę Szczęścia, niemalże z zewnątrz przyjrzeć się Utopii. Ale wszystkich wychowywano w przekonaniu, że poza nią czeka tylko chaos i śmierć.

Dla zrodzonego w Utopii dziecięcego ego sama ideologia, podniesiona do rangi religii państwowej i wyrażona przez wzniosłą symbolikę solarną daje pewność ontologiczną, niezbędną do poczucia szczęścia. Bohater bez zastrzeżenia wierzy, że żyje "w najszczęśliwszym społeczeństwie świata”, współczuje tym, którzy nie mogą tego doświadczyć. "Pamiętam wesołe piosenki pionierskie, dobiegające

${ }^{8}$ A. Walicki, Rosja, katolicyzm i sprawa polska. Warszawa 2003, s. 116. 
z głośników szkolnego radia w słoneczne wiosenne dni. W Mieście Słońca zawsze świeciło słońce" (s. 74).

W 1962 roku, trzy lata przed narodzinami Klinaua, Tamara Miansarowa po raz pierwszy odśpiewała hymn komunistycznych dzieci o słońcu i jeszcze $\mathrm{w}$ tym samym roku zwyciężyła dzięki niemu w konkursie pieśni młodzieżowej w Helsinkach, a rok później wygrała festiwal w Sopocie. Refren znany jest powszechnie na Węgrzech, i to w rosyjskim oryginale: „Пусть всегда будет солнце / Пусть всегда будет небо / Пусть всегда будет мама / Пусть всегда буду я". Tekst jest dziełem sowieckiego poety, Lwa Oszanina, ale refren powstał już wcześniej. Według legendy, sowieckie „Fiat lux" stworzył w 1928 roku czteroletni Kostia Barranikow, po tym, jak wyjaśniono mu, co oznacza słowo „zawsze”. Czterowiersz został opublikowany $\mathrm{w}$ jednym z czasopism pedagogicznych, stamtąd zaś trafił do książki Kornieja Czukowskiego pt. Od dwóch do pięciu. Lwa Oszanina natchnął plakat, na którym widniał pierwszy wiersz refrenu. Dwa pierwsze słowa dały tytuł piosence: Солнечный круг, czyli Stoneczny krag. Nie tylko pionierzy, ale i przedszkolaki, często śpiewały ten utwór. Sowiecka propaganda rozpowszechniła go $\mathrm{w}$ charakterze symbolu pokoju, a jako towar eksportowy pełnił rolę niesamowicie infantylnego przesłania pokojowego, przykrywki dla zaborczych zamiarów.

Obywatel Utopii nie może przekroczyć poziomu wiedzy czterolatka. Jeśli rozwój osobowości nie zatrzyma się na tym wczesnym etapie, to duchowo się od niej oddziela. To samo dzieje się z naszym bohaterem, który ogląda smutny film "pewnego chmurnego, ciemnego zimowego dnia". Film opowiada o psie, zostawionym sobie samemu po śmierci pana. Kiedy zwierzę chce wrócić do domu po pogrzebie, nikt już nie otwiera mu drzwi. W ten sposób „pewnego zimowego dnia to szczęście się skończyło" (s. 75-76). Wraz z utratą szczęścia ustaje również stan łaski, pozostawanie poza historią. Prymitywna sowiecka konstrukcja tożsamości staje się iluzoryczna, trzeba cofnąć się w czasie, odszukać tę tożsamość, którą utopia zniszczyła i zmarginalizowała. W trakcie tej odkrywczej podróży przekraczamy odgraniczające cywilizacje linie podziału.

Znajdujemy się strefie zderzenia, gdzie polsko-litewski mit Jagiellonów przez stulecia mierzył się z rosyjskim mitem trzeciego Rzymu. Przodkowie dzisiejszych Białorusinów żyli w rozciągającym się od Bałtyku do Morza Czarnego Wielkim Księstwie Litewskim, gdzie ich mowa odgrywała rolę języka pisanego w państwie. Idea Jagiellonów głosiła wielką integrację, bazującą na różnorodności języków, wyznań i kultur, i jako taka również dziś stoi w opozycji wobec imperialnej Eurazji. U Czesława Miłosza państwo Jagiellonów jest antytezą imperium, Commonwealth, które przez długi czas było potężniejsze od Germanów i Moskwy, zwyciężyło Krzyżaków i Iwana Groźnego9. Klinau w następujący sposób odróżnia je od „przyszłego Imperium Zła”: „Kraj przypominał Imperium, a jednak nim nie był.

${ }^{9}$ Por. Cz. Miłosz, Rodzinna Europa. Warszawa 2004, s. 20. 
Mógłby zostać Imperium, lecz stał się Demokracją" (s. 21). W wyniku wschodniego zagrożenia w 1569 roku Litwini i Polacy zawarli unię lubelską, dzięki której rzeczywiście powstało wspólne państwo, i już nie tylko osoba władcy wiązała Wielkie Księstwo Litewskie i Królestwo Polskie. Mimo że tradycja ukazuje oba narody jako sprzymierzeńców, złączonych wspólnotą losów, autor Miasta Stońca opisuje Rzeczpospolitą Obojga Narodów z ważną poprawką, jako „sojusz dwu Krajów i wszystkich zamieszkujących je narodów, które w przyszłości po bratersku przejdą razem dwieście lat kolonialnej historii" (s. 21). Bohater duchowej autobiografii znajduje tu europejską odmianę białoruskiej tożsamości, która tylko w ukrytej formie mogła przetrwać imperialną kolonizację. Podbój łączył się z ogromną liczbą ofiar ludzkich i katastrofą cywilizacyjną: „Sięgający od morza do morza Titanic szedł na dno, zgruchotany dziewięcioma ciosami otrzymanymi w ciągu dwu stuleci, dziewięcioma wojnami, z których jedna okazała się śmiertelna" (s. 22).

W trakcie kolonizacji zabroniono używania stosowanego od XIV wieku jako „nazwa-widmo" określenia „Białoruś”, tak samo jak w przypadku „Litwy”. W połowie XIX wieku, na stworzonym na jej terenach „Kraju Północno-Zachodnim” „litewska arystokracja - spadkobierczyni nazwy i tradycji Wielkiego Księstwa - była już niemal całkowicie zniszczona przez Imperium" (s. 58). Później historyczną misję walki $\mathrm{z}$ kolonializmem przejęły niższe warstwy społeczne. Był to przewrót kopernikański: po zdławionych powstaniach „walki narodowo-wyzwoleńcze" przerodziły się $\mathrm{w}$ terror jednostkowy i masowy. Celem stało się nie zwycięstwo sprawy narodowej, ale dążąca do obalenia Imperium rewolucja.

Choć w Mińsku również znajduje się komunistyczne sanktuarium, czczony niczym świątynia Domek, gdzie przy końcu XIX wieku odbył się pierwszy kongres partii, to świętym miastem rewolucji stał się Leningrad. Jako że utopia urządziła się $\mathrm{w}$ dekoracjach świata pozahistorycznego, nie chciała poznać własnej przeszłości, która mogła przejawiać się tylko w formie rytualnej. Jeśli jednak szukamy historycznego wyjaśnienia zwycięstwa rewolucji, to może być ono pojmowane jako radykalna odpowiedź na kolonizację terenów północno-zachodnich. Ponieważ była to zła odpowiedź, mogła jedynie stworzyć jeszcze bardziej tyrańskie imperium, które prowadziło politykę kolonizacyjną okrutniejszą od wszystkich poprzednich. Ale Klinau tylko zaznacza ten kontekst, koncentrując się raczej na wizualnym opisie antropologicznym Miasta Słońca, i poprzednie wydarzenia historyczne też przedstawia $\mathrm{z}$ takiego punktu widzenia.

Już kolonizację z XIX wieku autor pokazuje jako kulturowy genocyd i „mordowanie miast". Ponieważ Imperium określało się przede wszystkim jako rywal Europy, w pełnej rozciągłości chciało unicestwić europejskie dziedzictwo kulturalne Białorusi. 
$\mathrm{Na}$ początku, w 1830 roku, zburzono centrum Brześcia, jednego z najpiękniejszych miast Krainy. W miejscu, gdzie stało niegdyś mnóstwo barokowych klasztorów i kościołów, Imperium wzniosło potężną cytadelę - Twierdzę Brzeską z koszarami i placami musztry. Później zburzono lub przebudowano również inne miasta. W większości zniszczono ratusze, zbędne już w Imperium symbole niegdysiejszej wolności i prawa magdeburskiego. (s. 42).

Prawosławie także stało się narzędziem kolonizacji: zburzono dwie trzecie z trzystu dwudziestu dwóch greko- i rzymskokatolickich klasztorów, zaś w 1839 roku zakazano wyznania unickiego, niezwykle osłabiono i zrusyfikowano nauczanie. Po upadku powstania z 1863 roku zburzono działające wciąż w miastach katolickie kościoły i klasztory:

W Krainie, którą od wieków zamieszkiwali zgodnie katolicy, unici, prawosławni, protestanci, żydzi i muzułmanie, która przyjmowała uchodźców religijnych z innych krajów, na przykład staroobrzędowców z Rosji, delegalizowano całe wyznania. (s. 44).

To samo stało się i ze stolicą: „dwa wieki kolonialnej historii zmyły z jej paznokci europejski lakier" (s. 41). Ważnym przystankiem na drodze rozwoju duchowego bohatera dorastającego w Mieście Słońca oraz odzyskiwania prekolonialnej przeszłości był moment, w którym widzi on ryciny, obrazujące różne części Mińska. Wówczas poznaje tak różne od wspomnień z dzieciństwa, a tak bliskie Wilnu „miasto bardzo europejskie”:

spadziste dachy kryte dachówką, wieże kościołów, ratusz, kolegium jezuickie, niesamowite zespoły architektoniczne. Później dowiedziałem się, że Mińsk i Wilno faktyczne projektowali ci sami architekci. Miasto było katolicką stolicą tej krainy. Zanim przyszło tutaj Imperium, na terytorium Mińska znajdowało się dwadzieścia osiem katolickich i unickich klasztorów i kościołów, i zaledwie jedna cerkiew prawosławna. Na samym tylko Górnym Rynku stało aż pięć barokowych katedr. Nie zniszczyły ich wojny; zburzono je lub w dziewiętnastym wieku przebudowano. (s. 41-42).

Dlatego odgrywają tak wielką rolę w przebudzeniu duchowym bohatera, bowiem w zbudowanym na północnych terenach barokowym mieście odnajduje on otoczenie architektoniczne, wyrażające dawną tożsamość europejską, którego pozbawiony został Mińsk.

Klinau, pokazujący nam Miasto Słońca, jest zarazem plastykiem i pisarzem, tekst tworzy książkę wyłącznie wraz ze zdjęciami, prezentującymi najważniejsze place i budynki. Karierę Klinaua można porównać z życiem Brunona Schulza, który na początku spełniał się w grafice. Natchnieniem dla cyklu zatytułowanego Xięga bałwochwalcza stało się główne dzieło Sacher-Masocha, Wenus w futrze; później także w prozie Schulz konstruował podobne do nich sceny. W powstałym w 1920 roku ex libris Stanisława Weingartena Władysław Panas odnalazł ilustrację dzieła odkupienia. Ujętą $\mathrm{w}$ dzieło życia swoistą teologię mesjanistyczną rozumie 
on $\mathrm{w}$ ten sposób, że tworzy ona przejścia pomiędzy częściami tekstowymi i graficznymi. Drugą książkę Schulz stworzył jako pisarz i grafik, rysunki nie są tu tylko ilustracjami ${ }^{10}$. Klinau rozpoczął swoją karierę jako artysta plastyk, a projekt Miasto Słońce to przedsięwzięcie multimedialne. Napisał też powieść. Jego interpretatorzy muszą zatem poruszać się $\mathrm{w}$ różnych dziedzinach sztuki.

Na zdjęciach Klinaua Mińsk jest taki, jak przesiąknięte majestatyczną melancholią fragmenty miasta u Chirica, wznoszące się na ogromnych, pustych placach monumentalne budynki o charakterze twierdzy i zagadkowym przeznaczeniu. Tu jednostka ginie jak zabawka tytanicznych sił, wyłączona jest $\mathrm{z}$ jakiejkolwiek przestrzeni prywatnej, wystawiona na widok publiczny, w oślepiającym świetle czeka na wyrok. Wszystkowidzącym okiem jest tutaj palące słońce. Ale późną nocą wszystko się zmienia. Autor opisuje, jaki widok wita przybysza, jeśli koło północy przejeżdża autem pomiędzy pałacami.

O tej porze Miasto jest już praktycznie puste, ale nadciągający poranek wciąż jeszcze nie zgasił iluminacji nieskończonych szeregów Pałaców. Sztuczne światło podkreśla istotne detale, kryjąc w mroku wszystko, co nieważne, co odwraca naszą uwagę za dnia. Fasady Pałaców przypominają negatywy zdjęć. Światła i cienie zamieniają się miejscami. Za dnia światło pada z góry, rysując cienie na ziemi. Teraz zaś z dołu, i cienie uroczyście wędrują tam, skąd przybyły, w czarną otchłań nocnego nieba. Gdybym musiał dobrać muzykę odpowiednią do tej pory w Mieście Słońca, mój wybór padłby na Memorial Michaela Nymana.

Jeśli utrzymując idealne tempo $\mathrm{w}$ niecałe dwanaście minut pokonujemy ośmiokilometrową drogę, wiodącą "pośród żałobnych i wzniosłych Pałaców”, to Miasto wzbudza w nas „niezrozumiały pociąg”, dostajemy się we władzę „dziwnego nekroromantycznego erosu” (s. 84-85).

Klinau na przykładzie różnych budynków pokazuje okresy imperialnej estetyki, tworzącej Miasto Słońca. Dwa dziesięciolecia przedwojenne charakteryzował ortodoksyjny konstruktywizm, którego nie da się porównać z dekadenckim budownictwem socrealistycznym. Twórczość kończyła się wówczas na wzniesieniu konstrukcji, dopiero po wojnie rozprzestrzeniła się dekoracyjność. Druga wojna światowa odgrywa niezwykle ważną rolę we wciąż żywej komunistycznej mitologii miasta. Klinau, pisząc o tym, znacząco odchodzi od oficjalnej wersji (jeśliby tego nie uczynił, nigdy nie uwolniłby się od Utopii).

Według eposu opiewającego wielką moskiewską walkę patriotyczną, bohaterscy członkowie ruchu oporu zamordowali głównego komisarza III Rzeszy, Wilhelma Kube. W rzeczywistości zlikwidowała go Moskwa, ponieważ okazał się

${ }^{10}$ Ariko Kato opisała utwór jako całość wizualno-tekstową. Ksiega jako topos pisania i rysowania. Ilustracje Brunona Schulza do Sanatorium pod Klepsydrą. W: Bruno Schulz jako bohater literacki - Schulzowskie inspiracje i interpretacje. Notatki literackie i naukowe IV Międzynarodowego Festiwalu Brunona Schulza w Drohobyczu. Drohobycz 2010, s. 206-207. 
nadmiernym pragmatykiem. Miał plany wobec Białorusinów, zamierzał wznieść pod nazwą Asgard święte miasto w okolicach Mińska, bowiem tu, jego zdaniem, znajdowała się kolebka bóstw starogermańskich. Zamachem tym Stalin sprowokował odwet niezbędny bohaterskiemu duchowi, ponadto $w$ latach okupacji upamiętniał rocznice rewolucji i święta chrześcijańskie nalotami powietrznymi (w kościele benedyktynów odprawiano właśnie mszę wielkanocną, gdy trafiła W niego bomba). W ten sposób oczyszczono przestrzeń pod budowę, gdzie „rozpoczęto konstruowanie idealnej geometrii Miasta dla idealnej geometrii Społeczeństwa" (s. 81). Niemcy w końcu budowali jednak nie Asgard, ale Miasto Słońca, jako pokutujący aż do 1956 roku pracą przymusową jeńcy wojenni.

Bombardowania tak naprawdę służyły jako prace wstępne wielkiej budowy, bowiem zlikwidowały wszystko, co przypominało o przeszłości. Oszczędzono jednak pałace wzniesione $\mathrm{w}$ okresie sowieckim, chociaż były najłatwiejszym celem, a władze okupantów z III Rzeszy ulokowały się w nich, ponieważ idealnie odpowiadały nazistowskiej estetyce. Pałace dawnego imperium wznosiły się pośrodku rumowiska.

Twardo trzymały się ziemi grubymi łapami i przypominały bulteriery, groźnie spoglądające na przechodniów, gotowe w każdej chwili skoczyć i rozerwać ich na strzępy. W ich przykucnięciu wyczuwało się moc epoki, w której Kraina Szczęścia była silna swoją wiarą, silna tak bardzo, że kiedy Metafizyk oznajmił, że krew to wino, wszyscy nie tylko w to uwierzyli, ale i chłepcąc krew, wpadli w ekstatyczne delirium. (s. 116-117).

Po wojnie fanatyczną ascezę zastąpiła iluzja bogactwa. Zawiłe koncepcje stworzyły irracjonalne strefy, charakterystyczne dla powieści Franza Kafki i Eliasa Canettiego. Studiujący architekturę flâneur w paradoksalnych konstrukcjach miasta rozpoznaje odnajdywane we własnej tożsamości tajemnice. Jeśli idealna geometria Miasta Słońca przywołuje przed naszymi oczami strukturę społeczną Utopii, niemożliwa geometria wskazuje $\mathrm{z}$ nagła na absurd istnienia. Takie odkrycie serwuje Dom Telewizji,

którego monumentalna kolumnada, wzorowana na perystazie starożytnej egipskiej świątyni w Luksorze, zestawiona została z konstruktywistyczną fasadą, z której nieśmiało wychylał się barokowy portal przypominający fronton kościoła Il Gesù w Rzymie. (s. 121-122)

Na przedwojenną konstruktywistyczną fasadę maleńkiego palazzo na rogu ulic Marksa i Komsomołu „nanizano jeden pod drugim kilka rzędów miniaturowych kolumn korynckich, a ascetyczne wejście opleciono skomplikowanym gipsowym ornamentem roślinnym". Dla podmiotu uciekającego z Utopii są to tajemnicze wiadomości przychodzące od nieznanego nadawcy, które może zrozumieć tylko ten, kto zostawił za sobą dziecięcy, bajkowy świat Utopii: „odkryłem piękno, którego nie potrafiłem dostrzec, kiedy byłem dzieckiem. Jakkolwiek to dziwne, od- 
krycie to stało się możliwe dopiero wówczas, kiedy na zawsze porzuciłem Krainę Szczęścia" (s. 121-122).

Klinau nie twierdzi, że zastępująca zasady konstruktywizmu historyzująca dekoratywność, dekadencki socrealizm wyprzedzający najbardziej rozwinięty świat stworzyły tu postmodernistyczny eklektyzm. Choć wschodni mistrzowie nieistniejącego jeszcze postmodernizmu nawet ze słyszenia nie znali społeczeństwa dobrobytu, trafił się im taki zleceniodawca, który na wiele mógł sobie pozwolić. Konstruktywistyczne bunkry manifestowały wejście w nowy okres przez społeczeństwo odrzucające swoje kulturalne dziedzictwo, stworzenie nowej estetyki, która wyraża konsekwentną pracę twórczą. Po wojnie obraz zwróconego ku przyszłości społeczeństwa trudzącego się urzeczywistnieniem utopii został zastąpiony przez wizerunek podbijającego glob imperium, odnoszącego zwycięstwa na skalę światową. Mocarstwo to nie jest w ruchu, nie możemy powiedzieć, że dokądś dąży, bowiem dotarło już na miejsce. Zostało poddane porównaniu i okazało się, że nie ma od niego mocniejszego. III Rzesza tylko uzurpowała sobie wiekuistość, Moskwa z kolei, jak kanibal rytualnie pożerający przegranego, zawłaszczyła atrybuty upadłego zdobywcy świata.

To mocarstwo nie jest już częścią historii, lecz wykroczyło poza nią. Inaczej rzecz ujmując, stało się postmodernistyczne. Majestatyczny spokój wiekuistości potrafi wyrazić tylko pełen zasób środków zamkniętej historii. A z rogu obfitości sypało się na fasadę pałaców

wszystko, co tylko człowiek wymyślił w ciągu tysiącleci istnienia wszelkich możliwych stylów. Był tu i starożytny Rzym, i Grecja, i Egipt, i barok, i renesans, i nawet tajemne znaki okultystyczne. Widać budowniczowie Utopii wierzyli, że estetyka Szczęścia musi zawrzeć w sobie osiągnięcia wszystkich poprzednich kultur. (s. 118)

Język nie umie dotrzymać kroku temu wielkopańskiemu zadęciu, pozostaje katalogowanie martwej kultury, pusta enumeracja:

barokowe frontony z pięcioramiennymi gwiazdami pośrodku, antyczne wazy, rogi obfitości, urny, kolumny i pilastry korynckie, toskańskie i jońskie, egipskie obeliski, balustrady, medaliony, rozety, ślepe okna i balkony, a także, oczywiście, cała masa kultowych symbolów: pięcioramiennych gwiazd, sierpów, młotów i nawet masońskich cyrkli. (s. 118)

Ale nie tylko wielkimi słowami można opisać ten ciąg pałaców, bowiem chełpliwa reprezentacja wiodła ku całkowicie niepoważnym rozwiązaniom architektonicznym. Jak gdyby zamawiający przeznaczył największą część środków pieniężnych na stworzenie świata iluzji. Wzniósł dwa rzędy dekoracji w wielkiej pustce. Jeśli chcielibyśmy opisać miński Prospekt za pomocą postmodernistycznej terminologii architektonicznej, dobrze posłuży nam do tego celu klasyczny przy- 
kład Las Vegas, podany przez Roberta Ventury'ego ${ }^{11}$. Ciąg pałaców tak samo oddziela się od otoczenia, jak pasmo handlowe (commercial strip) od pustyni.

Venturi zalicza widoczne tu budynki do dwóch typów, jednym z nich jest kacz$k a$, która już swoją symboliczną formą zapowiada, co oferuje (dosłownie kaczkę), drugi zaś to udekorowana szopa (decorated shed). Ten ostatni to budowla, którą "obwieszają symbolami”, jej konstrukcja nie jest czysto architektoniczna, "może przyjąć napisy, obrazy, pomniki, plastikowe dodatki, przybudówki etc.". Całe pasmo charakteryzują „zróżnicowane środki przekazu”, , "roi się ono od znaczeń, tłoczą się w nim wyrażenia". Przekaz musi rzucać się w oczy i być frapujący, żeby również kierowcy zwrócili na niego uwagę ${ }^{12}$. A ponieważ duch kupiecki jest obcy Prospektowi, nie znajdziemy w nim kaczki (trudno byłoby sobie wyobrazić budynki stanowiące alegorię pojęć abstrakcyjnych), jednakże stykają się tu udekorowane szopy. Porządek tworzony jest przez siłę wyższą, to nie właściciele ujarzmiają ten chaos, dostosowując się do siebie podczas rywalizacji.

Klinau pisze, że ciąg pałaców imponuje tak naprawdę tylko frontami, jeśli zajrzymy za nie, podniosły nastrój natychmiast mija. Ale w takim razie dla kogo zbudowano pasmo chwały? Mieszkańców można byłoby przekonać i skromniejszą konstrukcją iluzoryczną. Mińsk jest wyjątkowy, ponieważ pozbawiono go historii. $\mathrm{W}$ ten sposób nie pozostało w przestrzeni miejskiej nic, co mogłoby przeszkodzić w konsekwentnej realizacji projektu. Jednocześnie samo Miasto Słońca było częścią ogromnej kompozycji euroazjatyckiej, jego architektura otrzymuje znaczenie tylko wtopiona w tę kompozycję. Nie jest niczym innym, niż „uwerturą, łukiem triumfalnym, Wrotami prowadzącymi do prawdziwego Miasta Słońca" (s. 83). Ale główne dzieło nie powstaje, bowiem decydenci nie są w stanie tak samo poświęcić Moskwy, jak Mińska. Tam pozostał "gigantyczny, energetyczny konglomerat", w ten sposób "cały wielki projekt utonął w ciele starego miasta". Powstaje tylko uwertura Idealnego Miasta - „przeznaczenie sprawiło, że uwertura ta stała się jedynym ucieleśnieniem Miasta Słońca, pierwszym i ostatnim, zbudowanym tutaj i tylko tutaj" (s. 83-84).

Mieszkaniec Utopii mógł najmocniej przeżyć upajające uczucie przynależności do centrum w czasie parad z okazji pierwszego maja i siódmego listopada - jeśli jeszcze nie utracił dziecięcej niewinności. Bohater przywołuje wspomnienia z dzieciństwa, z epoki Breżniewa, bowiem tylko tak umie pisać o tym z odpowiednim nabożeństwem. Najbardziej mistyczna część obrządków odbywała się w centrum centrów, na Placu Czerwonym, u zigguratu mauzoleum. W odróżnieniu od idealnej geometrii Miasta Słońca, to właśnie był najmroczniejszy chaos, Na ekranie telewizorów, zamiast jasności idei Utopii, pojawiały się archaiczne wieści eschatolo-

${ }^{11}$ R. Ventury, D. Scott Brown, S. Izenour, Learning from Las Vegas. The forgotten symbolism of architectural form. Cambridge 1972.

12 Vay Tamás, A posztmodern Amerikában. Tematikus napló. Budapest 1991, s. 11-15. 
giczne. Ziggurat jest symbolem Babilonu, szatańskiego imperium zagrażającemu Królestwu Bożemu, chociaż ten moskiewski nie kryje posągu Boga, a zmumifikowane zwłoki. Bezpośrednio przed rozpoczęciem rytuału „kamera robiła zbliżenia na najważniejszy zegar Krainy Szczęścia - kuranty na Wieży Spasskiej” (s. 89-90).

To wszystko jest tak absurdalne, że nie da się tego opisać. Choć niemal zewsząd usunięto symbolikę chrześcijańską, wieża Kremla nosi miano Wieży Zbawiciela. Świętujący rewolucję lub ruch robotniczy Metafizyk jakby sugerował, że życie wieczne czeka tego, kto zasłuży na zbawienie - gwarancją jest mumia, która ciałem pozostała wśród swoich wyznawców.

Istnieje też inne święto, nie eschatologiczne, a czysto imperialne, dlatego i dziś obchodzone, bowiem przetrwało upadek Utopii. 9 maja - Dzień Zwycięstwa - jest niezwykle ważny ze perspektywy tożsamości białoruskiej, bowiem bez żadnych zmian przeszedł $\mathrm{z}$ repertuaru stalinowskiego do eposu putinowskiego. Kto tego dnia świętuje na Kremlu, usprawiedliwia kolonizację podbitych terenów, z zachodnim hegemonem zastępczym na czele. $Z$ opisu wynika, że bohater już w dzieciństwie podejrzewał coś na temat kłamstw złowieszczej parady: „Prospektem do placu Zwycięstwa szli niekończącą się kolumną staruszkowie i staruszki z piersiami usianymi krążkami i gwiazdkami orderów i medali. Zawsze zdawało mi się, że ciągnie się za nimi jakiś trupi zapach" (s. 92).

$\mathrm{Z}$ tej duchowej autobiografii wyłania się następujący obraz: bohater jako dziecko był szczęśliwym mieszkańcem Utopii, na pograniczu dorosłości zmienił się stan jego ducha (miał siedemnaście lat, gdy zmarł Breżniew, co w książce też stanowi symboliczną granicę). Z iluzorycznego świata dzieciństwa wyruszył ku historii, by odnaleźć ukrytą tożsamość białoruską. Kim stał się utracony obywatel Utopii? Przechodniem, skrywającym się w bramach przed promieniami słońca, pokrewnym Benjaminowskiemu flâneurowi, przed którym odsłaniają się tajemnice miasta. Formułuje swoje odkrycia z perspektywy plastyka i pisarza. Jako pisarz określił się już wówczas, kiedy zdecydował, że nie zerwie z językiem ojczystym. 